\title{
A THEME OF FAIRNESS REVISITED: LORD MANSFIELD'S LEGACY FOR A HOLISTIC THEORY OF CONTRACT TODAY
}

\section{C.M.A.McCauliff}

The $20^{\text {th }}$ century Anglo-American formulation of contract is a response to two major concerns, values or fairness in the $18^{\text {th }}$ century as symbolized in the great cases of Lord Mansfield, Chief Justice of the King's Bench, and freedom of contract, which limited liability during the $19^{\text {th }}$ century manufacturing and entrepreneurial age. When the limitation on liability caused too much hardship, concepts of equity were used to mitigate the harshness of the law. But that muddled our theory of liability. While we had a holistic approach under Mansfield, we now arguably have a bifurcated approach, the bargained-forexchange contract of the market place, and the trouble-shooting equitable notions of promissory estoppel to redress injury flowing from reliance on incomplete bargain. Some 20 years ago, this situation concerned Justice Robert Braucher of the Supreme Judicial Court of Massachusetts, Reporter until 1971 for the Restatement (Second) of Contracts.

I intend to explore the permutations of promissory and equitable considerations in contract theory by comparing the serviceability of the promissory and the equitable theories of liability at two very different points in time, the $1780 \mathrm{~s}$ and the 1970s. The unsettled conditions in the contract law of Lord Mansfield's time, the reaction against his insights by 1840 and the subsequent need to restore the balance with promissory estoppel allow us to put in perspective Justice Braucher's seemingly revolutionary conclusion that we no longer needed promissory estoppel in the bid situation described in Loranger Construction Co. v. E.F. Hauserman Co. ${ }^{1}$ In Loranger, a general contractor sued when a

\footnotetext{
- Professor of Law, Seton Hall University School of Law, and Samuel I. Golieb Fellow in Legal History at New York University School of Law (1998/99).

1384 N.E. 2d 176 (Mass. 1978). Justice Braucher's successor as Reporter, Restatement (Second) of Contracts includes a brief biographical note about Justice Braucher in his treatise on Contracts: E. Allan Farnsworth, Contracts (Aspen Law and Business, New York, $3^{\text {rd }}$ ed., 1998) notes that Justice Braucher (1916-81) "was a decorated pilot during World War II
} 


\section{THE DENNING LAW JOURNAL}

subcontractor, the low bidder, withdrew after the general contractor had submitted its own bid; the general contractor had to engage another subcontractor at a higher price. Justice Braucher allowed the general contractor to recover from the subcontractor using the general contractor's reliance on the subcontractor's bid as consideration. He also tried to heal the division in theory by stretching the bargain to encompass a greater range of fact patterns. While promissory estoppel is the obvious theory excluded during the $19^{\text {th }}$ century, the echo of equity in Lord Mansfield's enforcement of moral consideration, which the $19^{\text {th }}$ century also rejected, bears re-examination in the journey from James Baird Co. v. Gimbel Bros. $^{2}$ and Drennan v. Star Paving Co. ${ }^{3}$ the leading American cases in the area, to Loranger. Here several of Lord Denning's cases may prove illuminating.

\section{I.BALANCING THE DEMANDS OF CONSIDERATION IN THE $18^{\mathrm{TH}}$ CENTURY}

In the third quarter of the $18^{\text {th }}$ century, Lord Mansfield, while Chief Justice of the King's Bench, faced a different version of the same problems involved in Baird and Drennan and tried to realign consideration. In attempting to make sense out of consideration, Mansfield cast about for categories. Since the courts did not inquire into the adequacy of consideration, he suggested that consideration served a formal rather than a substantive function and began by emphasising its evidentiary role in indicating intent to contract. ${ }^{4}$

Pillans v. Van Mierop, Mansfield's first case involving consideration, concentrated on the intent of the parties to be involved in the arrangement, with a letter from a merchant banker in London, saying "I will give the bill due honour" as the principal indication of the commercial arrangement, that is, accepting the plaintiffs' drafts for payment. ${ }^{5}$ Mansfield regarded a writing and consideration as

before becoming a member of the Harvard law faculty were he taught for a quarter of a century." [at p.861].

264 F. 2d. 344 (2d. Cir. 1933).

333 P. 2d. 757 (Cal. 1958).

4 John F. Wilson, "The Enforcement of Promises in Anglo Amercian Law" (1958) 32 Tulane

L. Rev. 371 at p.375 Compare Chief Justice Benjamin N. Cardozo's statement that consideration "came into the law, not so much from any reasoned conviction of its justice, as from historical accidents of practice and procedure" in Allegheny College v. Chautauqua Bank 159 N.E. 173 at 175 (N.Y. 1927). See Alfred S. Konefsky, "How to Read, or at Least Not Misread, Cardozo in the Allegheny College Case" (1987) 36 Buffalo L.Rev. 645.

5 Pillans v. Van Mierop (1765) 3 Burr. 1664; 97 Eng. Rep. 1035, [K.B.]. The plaintiff, Pillans and Rose, a firm of merchants in Rotterdam, advanced $£ 800$ to White, a merchant in Dublin, who wrote to the merchants in Holland asking to draw a bill of exchange upon them for $£ 800$ 


\section{LORD MANSFIELD'S LEGACY}

"alternatives," functional equivalents evidencing the intent of the defending promisors to be bound at the time the agreement took place. ${ }^{6}$ The question for the court in economic terms was, who should bear the ultimate risk of bankruptcy in the chain of negotiability, expressed in the issue, did the defendant merchant bankers make a valid acceptance of the merchants' bill? ${ }^{7}$ The court held for the plaintiffs, the Dutch merchant firm, on the alternative grounds that no consideration was needed in the first place if the promișe was in writing and related to a transaction between merchants. In any event Mr. Justice Wilmot found consideration insofar as the merchants in Rotterdam were "deluded and diverted from using any legal diligence to pursue White."

payable to Clifford, if he could make a similar arrangement for the merchants with a sound bank in London. The defendants, Van Mierop and Hopkins, a merchant banking firm in London, pledged in writing to honour bills of exchange, in answer to the Dutch merchants' letter to the bank stating the merchants' intention to draw on the bills the next month using White's credits at the bank. White failed, the London bank found out and the Dutch merchants could not draw on the London bank, although White had clearly deposited money with the London bank. The defendants pleaded that there was only past.consideration for their commercial undertaking to honour a negotiable instrument because their promise given in the answer to the merchants was written after the merchants had already extended their credit to White. Kevin M. Teeven, "Mansfield's Reform of Consideration in Light of the Origins of the Doctrine" (1991) 21 Mem. St. U. L.Rev. 669 at p. 683. Michael Lobban, The Common Low and English Jurisprudence 1760-1850 (Oxford, Clarendon Press, 1991) at p. 109. A.W. Brian Simpson, A History of The Common Law of Contract: The Rise of The Action for Assumpsit (Oxford, Clarendon Press, 1975) at pp.323 \& 617.

${ }^{6}$ Simpson, ibid at p.617.

7 A bill of exchange (which was assignable and negotiable) carried its consideration with it, and thus set up a rebuttable presumption. According to convention, it was already wellestablished doctrine that bonds and notes were prima facie evidence of consideration without proof. Lobban, supra n.5 at pp. 108-109.

${ }^{8}$ The late Professor Samuel J. Stoljar, A History of Contract at Common Low (Australian National University, 1975) at pp.103-104 characterised Mr. Justice Wilmot's view as more extreme than Mansfield's, and drew on J.M. Holden, History of Negotiable Instruments in English Law (London, Athlone Press, 1955) to make sense of Pillans: "White had every right to assign the money, and... [the merchants'] letter to the defendants could be taken as completing the assignment, as the latter were now charged with notice that White's assets were booked for the new assignees." [at pp.135-136]. Furthermore, Professor Stoljar reminded us that $18^{\text {th }}$ century commercial law was extremely complicated: "It is of course true that such an informal assignment or transfer of a debt was not possible at common law. Yet it must be plain that, had such an assignment been possible (as it was to become possible in equity), the case would have found a much simpler solution, nor would it have given rise, then or later, to some of the extravagent prouncements which it did." [at p. 104] 
The merchants said they extended credit to White only after White referred them to the bank in London. The best known passage from the opinion is Mansfield's statement that:

\begin{abstract}
"the ancient notion about the want of consideration was for the sake of evidence only: for when it is reduced to writing, as in covenants, specialities, bonds etc. there was no objection to the want of consideration. And the statute of frauds proceeded upon the same principle."
\end{abstract}

Mansfield said that the law merchant did not have a doctrine of consideration. ${ }^{10}$ If negotiable instruments do not require consideration, then was Mansfield simply attempting to do away with consideration by using as a vehicle a fact pattern that did not require consideration in order to find a valid contract?" Simpson says that Mansfield's emphasis on consideration as fulfillment of an evidentiary function is less historically suspect than generally assumed. $^{12}$

${ }^{9}$ Theodore F.T. Plucknett, Concise History of the Common Law (Little, Brown, Boston, $5^{\text {th }}$ ed., 1956) at p.654 showed that Mansfield was on strong grounds with his evidentiary point since the Statute of Frauds, 1677 (29 Car.2.c.3), together with sound business practices, took care of many difficulties in proving contracts. Samuel J. Stoljar, "Estoppel and Contract Theory" (1990) 3 J. Cont. L. 1, noted that the "first great wave of estoppel arose with oral agreements concerning interests in land required to be in writing under the Statute of Frauds."[at p.3] In Pillans, the three other judges of the King's Bench agreed with Lord Mansfield. Lon L. Fuller, "Consideration and Form" (1941) 41 Colum .L. Rev. 799 at p.799 $\mathrm{n} .1$, writing of the evidentiary function of consideration, related Mansfield's objection to consideration to the form and manner in which the promise is made, citing Pillans.

${ }^{10}$ Pillans $\mathrm{v}$. Van Mierop supra $\mathrm{n} .5$ at $1669 ; 1038$.

"Kevin M. Teeven, A History of Anglo-American Common Law of Contract (Greenwich Press, New York, 1990) at p. 152. It is difficult to believe that the irrelevance of consideration (or that it was a conclusive presumption) to a negotiable instrument escaped Lord Mansfield. David Lieberman, The Province of Legislation Determined: Legal Theory in Eighteenthcentury Britain (Cambridge University Press, 1989), rehearsed Lord Mansfield's relations with the merchant community: "During his practice at the bar he was retained by London merchant groups, and throughout his judgeship he maintained regular social and professional contact with the City's leading figures... He extended the practice utilized by his predecessors of soliciting professional testimony to prove and clarify merchant usage in the courts... Besides enlisting this professional advice and guidance, the Chief Justice took equal pains to ensure that the actions of his court were correctly perceived by the merchants themselves... More important and more distinctive was his use of special juries composed of merchants for the trial of commercial disputes." [at pp. 111-113].

${ }^{12}$ Simpson, supra n.5 at pp. 323, 407, 442 \& 617-19 


\section{LORD MANSFIELD'S LEGACY}

Even before other judges began to back away from the implications of Pillans for consideration outside negotiable instruments, Lord Mansfield began to take a somewhat different tack. ${ }^{13}$ After this approach of holding verbal agreements binding on evidence of intent ran into trouble, Mansfield set forth a modified position on consideration. Instead of ignoring consideration as unnecessary, he said consideration is easily met. Mansfield's second position, like his first, revolved around a party's intention to be legally bound. ${ }^{14}$ These

${ }^{13}$ In Watson v. Turner (1767) Buller's N.B. 129, just two years after Pillans, Mansfield held at nisi prius that moral obligation constituted consideration. (An overseer of the poor promised to pay an apothecary who had given medical aid to a pauper in an emergency without first consulting the overseer.) Stoljar, supra n 8 at p.67 traces many of the $18^{\text {th }}$ century moral obligation cases to a decision in 1731 which the reporters Bosanquet and Puller disavowed in 1802 in their famous note to Wennall v. Adney 3 B. \& P. 247.

The reaction of the judges in the court of Exchequer Chamber against Pillans appeared in Rann v. Hughes (1778) 4 Brown, P.C. 27; 7 Term R. 350, note; 101 Eng. Rep. 1014 note; 2 Eng. Rep.18. Isabella Hughes, the administratrix of John Hughes who died intestate owing over $£ 900$, promised Rann, the executrix of $M$. Hughes, that she would pay Rann from her (Isabella's) own goods the debt John owed to M. Hughes, but Isabella later refused to pay; the estate had $£ 3000$ in assets, though the declaration failed to allege assets. Rann sued Isabella in King's Bench personally rather than as administratrix. Although Isabella pleaded no consideration, the King's Bench gave judgment against Isabella de bonis propriis, and not merely from the intestate's goods generally. Ordering reversal, Skynner, Lord Chief Baron of the Court of Exchequer Chamber, wrote the opinion for the House of Lords: "It is undoubtedly true that every man is by the law of nature bound to fulfil his engagements. It is equally true that the law of this country supplies no means, nor affords any remedy, to compel the performance of an agreement made without sufficient consideration." As Stoljar pointed out, the presumption of sufficient assets applied when a forbearance assumpsit was brought so why should it not when the Statute of Frauds implied a promise to pay would be good, provided it was in writing and signed by the party to be charged [supra n. 8 at pp.97-98]. For the law relating to legacies, see Simpson, supra n.5 at p.442.

${ }^{14}$ Cf. Clare Dalton, "An Essay in the Deconstruction of Contract" (1985) 94 Yale L.J. 997 "But if consideration is taken seriously as a doctrine of form, it would apply to cover all instances of detrimental reliance, making an additional doctrine of reliance unnecessary." [at p. 1088]. John H. Baker, "Origins of the Doctrine of Consideration, 1535-1585" in On the Laws and Customs of England (eds. M.S. Arnold et al )(University of North Carolina Press, 1981) at p.351, Mansfield attempted to revive Plowden's notion of intention to be bound as an aspect of consideration. Patrick S. Atiyah, Essays on Contract (Oxford University Press, 1986), says consideration finds a function "in reminding us always of the substantive grounds of liability behind the formal one of the promise or agreement or signature" [at p.127]. At first, Lord Mansfield had relied on estoppel by conduct, Christopher P. Rodgers, "Continental Literature and the Development of the Common Law by the King's Bench: c. 1750-1850" in The Courts and the Development of Commercial Law (ed. Vito Piergiovanni) (Berlin, Duncker \& Humblot, 1987) at p.190 (citing Montefiori v. M(1762) 1 W. Bl.363 [K.B.]. 


\section{THE DENNING LAW JOURNAL}

cases of moral obligation were not lost on Mr. Justice Denning in High Trees and its progeny.

Expanding consideration to include moral obligation met with rather more success than reducing consideration to a category of evidence, since moral obligation imported notions of equity and good faith into the assessment of the validity of an agreement. ${ }^{15}$ For example, a legatee brought an action in assumpsit against an executor with sufficient assets to pay the legacy. ${ }^{16}$ Lord Mansfield stressed the moral obligation arising from the executor's assent to the legacy, an actual promise and an undertaking to pay the legacy:
"and that promise [is] founded on a good consideration in law; ... it is the case of a promise made upon a good and valuable consideration which in all cases is a sufficient ground to support an action. It is so in cases of obligations which would otherwise only bind a man's conscience, and which without such promise, he could not be compelled to pay."

Mansfield held that since the assets were available to pay the legacy, that provided sufficient consideration to enforce the legacy because the executor was "compellable in a Court of Equity, or in the Ecclesiastical Court, to pay for it." The notion of moral obligation as equity is the other side of the coin of stretching consideration since it achieves the same result.

In another case lending itself to an analysis on the basis of moral obligation, a debtor about to go bankrupt bought a large quantity of inventory (linen) on credit. The debtor declared bankruptcy. Because the debtor promised to pay half the old amount after he emerged from bankruptcy, that is, the debtor waived discharge in bankruptcy, the linen merchant forewent the opportunity to file a claim in the defendant's bankruptcy proceeding. After the debtor's discharge in bankruptcy,

\footnotetext{
${ }^{15}$ Teeven, supra n. 5 at pp.697-698 and Atiyah, ibid at pp.32-33, 80, \& 133-34 characterise the influence of natural lawyers and philosophers of the Enlightenment as preferring reason over tradition which is supportive of the evidentiary nature of promises. James Gordley, The Philosophical Origins of Modern Contract Doctrine (Oxford, Clarendon Press, 1991) sums up their contributions at p. 109.

${ }_{16}$ Atkins v. Hill (1775) 1 Cowper 284 at 288 [K.B.]. The executor complained that the plaintiff's declaration did not specify the estate's assets or the consideration to support his promise. Rodgers, supra n. 14 at p. 190 notes that Rann v. Hughes reversed Atkins on its facts. 17 Atkins ibid at pp. 288-289

18 The executor denied liability in contract at common law. Stoljar, supra n.8, opined that "the question of consideration was here irrelevant since an executor with assets was as liable for a legacy as he was for the testator's debts.'[at p.97]
} 
the defendant debtor agrued that an old debt and a new promise amounted to a nudum pactum (unenforceable agreement). Mansfield invoked the principle of moral obligation: "all the debts of a bankrupt are due in conscience... and there is no honest man who does not discharge them, if he afterwards has it in his power to do so." $" 19$

Finally, in Hawkes v. Saunders, Mansfield dealt with another executrix who promised to pay a legacy without consideration. This time, however, there was no dispute about the adequate assets to pay the legacy:
"The whole case is reduced to this single point: Whether the circumstance of the defendant having assets to pay all the debts and legacies is or is not a sufficient consideration for her to make a promise to pay the legacy in question. ${ }^{20}$

Mansfield deliberately emphasised the "elasticity" of consideration by invoking morality, and managed to accomplish what he had desired to do without consideration. ${ }^{21}$ Mansfield's moral obligation cases have been summarised as centring on three qualities: "an affirmation of a prior moral duty, a promise supported by consideration grounded in conscience, and a promise that was enforceable in chancery when specific relief was available."22 Thus Mansfield took scattered precedents, and created unified standards and principles to enforce contracts which the parties intended to enter.

According to Sir David Parry, in the $18^{\text {th }}$ century, "moral obligation was regarded as the primary factor making promises enforceable; and the general climate... favoured freedom of contract and the enforcement of all contracts

19 Trueman v. Fenton (1777) 2 Cowper 544 at 548; 98 Eng. Rep. 1232, [K.B.]. The moral obligation to pay, in accordance with the promise given, furnished a sufficient consideration Rodgers, supra n. 14 at p. 190.

${ }^{20}$ Hawkes v. Saunders (1782) l Cowper 288; 98 Eng.Rep. 1091, [K.B.]. Without consideration an executrix promised to pay a legacy. Moral obligation constitutes consideration. Lord Mansfield restated his view: "As if a man promise to pay a just debt, the recovery of which is barred by the Statute of Limitations: or if a man, after he comes of age promises to pay a meritorious debt contracted during his minority, but not for necessaries: if a bankrupt, in affluent circumstances after his certificate, promises to pay the whole of his debts; or if a man promises to perform a secret trust, or a trust void for want of writing, by the Statute of Frauds."

${ }^{21}$ Cecil H.S. Fifoot, Lord Mansfield (Oxford, Clarendon Press, 1936) at pp. 140-141

${ }^{22}$ Teeven, supra $\mathrm{n} .5$ at p. 693 


\section{THE DENNING LAW JOURNAL}

freely entered into."23 James Oldham, who edited Mansfield's trial notes, assessed Mansfield's philosophy of contracts as focusing on peformance rather than the formalistic process of making a contract:

"But the evidence in Mansfield's trial notes, especially in terms of
the role of the jury, describes an equity-based approach centered
on the intentions of the parties and the avoidance of unjust
enrichment, rather than a theoretical approach centered on the
requisites of an enforceable executory contract."

Mansfield's position emphasizes equity and to some extent, therefore, the possibility of promissory estoppel.

Mansfield's embrace of equity requires the discretion to do justice in the circumstances of the case which may not be properly decided if an ironclad rule or bright-line test is followed in all situations. Under Lord Mansfield, judicial decision-making grew more complex, and extra work had to be done, as exemplified by the special merchant juries. On the one hand, there was the need to avoid uncertainty, and, on the other hand, there was also a great, constant need under this flexible system to relate both to underlying principles and commercial practices. Lord Mansfield knew that "as the usages of society alter, the law must adapt itself to the various situations of mankind."25

Mansfield used the "custom" of the trade in question and mercantile convenience to achieve the objective of certain but flexible principles. The opportunity to craft a more finely honed response to a legal problem carried with it the challenge and responsibility to keep the fundamental principles of the central core of contract law firmly in mind. Not every lawyer and judge wished to carry so heavy a burden that these high-minded principles demand, and some

${ }^{23}$ David H. Parry, The Sanctity of Contracts in English Law (London, Stevens, 1959) at p.51. Although the Restatement of Contracts $\$ \S 86-89$ (1932) had rejected moral obligation "as a form of consideration or a separate basis for enforcement," cases continued to multiply. ${ }^{24}$ James C. Oldham, The Mansfield Manuscripts and the Growth of English Law in the Eighteenth Century (University of North Carolina Press, 1992) at p.213

${ }^{25}$ Johnson v. Spiller (1784) 3 Doug. 371 at 373, [K.B.]. Oldham, ibid, assessed Mansfield's attitude to certainty and the importance of contract doctrine as follows: "Mansfield believed in the importance of certainty in mercantile transactions and in a few other contexts, but fairness, not certainty, was his lodestar for the general run of contract cases. This yielded a contract philosophy built around expectations and unjust enrichment. On the expectation side, the promise was central. Honoring expectations legitimately created by a promise was a moral necessity, and by doing so, the advantage of certainty in mercantile transactions would be upheld."[at p.242]. 
saw moral consideration as the imposition of private concerns on the law. Furthermore, Jeremy Bentham, using the criterion of utility, put a premium on certainty and predictability over broad ethical principles. ${ }^{26}$

\section{II.HIGH TREES PROVIDES AN EQUITABLE SOLUTION}

Mr. Justice Denning of the High Court of Justice (as he then was) decided a case, Central London Property Trust Ltd. v. High Trees House Ltd., which dealt with modifying a contract already in progress. ${ }^{27} \mathrm{~A}$ few years thereafter, he reflected on its implications for option contracts:

"But nowadays there are some grounds for suggesting that an act
may be good consideration even though it is not a benefit to the
promisor nor a detriment to the promisee... This new conception
of consideration may have an important bearing on the vexed
question of a promise to keep an offer open for a fixed time on
the faith of which the option-holder acts. The act done may be
good consideration even though it is no benefit to the promisor."28

At that time, Lord Denning seemingly continued to believe it possible to reform the doctrine of consideration to accommodate the needs of litigants.

The facts of High Trees involved modification of a contract already in operation. Mr. Justice Denning made no mention of detriment. In 1937, a company leased a block of flats to a subsidiary company, High Trees, at a ground rent of $£ 2,500$ a year. In January, 1940, after the wartime conditions caused many vacancies, the rent was reduced in writing to $£ 1,250$ with no time limit for the reduction. In 1945, the flats were full again and the receiver of the plaintiff company claimed the full rent and sued for the last two quarters of 1945 . High Trees "pleaded that the agreement for the reduction of the ground rent operated

${ }^{26}$ Francis H. Buckley, "Paradox Lost" (1988) 72 Minn. L. Rev. 775 at p.811 (utilitarians are consequentialists). Bentham in his later years criticised Lord Mansfield for his view that the courts, rather than the legislature, should reform the law, but earlier Bentham had praised Mansfield. William S. Holdsworth, "Lord Mansfield" (1937) 53 L.Q.R. 221 at pp.227 \& 230. For Bentham's criticism of the common law, see Lieberman, supra n.11 at pp.232-233 and Chapter 11 generally.

27 [1947] 1 K.B. 130.

28 Alfred T. Denning, "Developments in the Doctrine of Consideration" (1952) 15 M.L.R. 1 at pp.2-3. (Cf. Lord Denning's criticism of traditional offer and acceptance analysis in Esso Petroleum Ltd. v. Commissioners of Customs \& Excise [1975] 1 W.L.R. 406 at 408, [C.A.] [World Cup sales promotion]). 


\section{THE DENNING LAW JOURNAL}

during the whole term of the lease, and, as alternative, that the plaintiffs were estopped from demanding rent at the higher rate or had waived their right to do so down to the date of their letter of September 21, 1945."

In England, promissory estoppel remains technically unavailable as a cause of action, and is used only as a defence. ${ }^{29}$ It therefore would have been available to High Trees in defence, except for another Victorian precedent which held that estoppel operates only on a misrepresentation of existing fact, and not for a promise of future conduct. To circumvent this obstacle, Mr. Justice Denning used the other Victorian cases which up to then had provided promissory estoppel's "finest hours." In dictum, he said that the plaintiffs could not have sued for the arrears accumulated during the period of the rent reduction, and even though High Trees could not have sued the plaintiffs for refusing to accept the reduced rent, the fusion of law and equity estopped the plaintiff from acting inconsistently with their promise.

The discussion of the issues in England, despite some differences in doctrine, is very illuminating for discussion of Loranger's fate. ${ }^{30}$ Some commentators greeted High Trees with resistance to changing the scope and role of consideration. ${ }^{31}$ The courts saw High Trees as an "innovation," if not "a

29 As Patrick S. Atiyah,in An Introduction to the Law of Contract (Oxford, Clarendon Press, $4^{\text {th }}$ ed., 1989) puts it, promissory estoppel is a way to "discharge contractural obligations but not create them" [at p.1] although he sees some signs of change. Richard Hooley, "Consideration and the Existing Duty" (1991) Journal of Business Law 19 suggests that in English law, promissory estoppel cannot give rise to a cause of action: "Although Lord Denning expressed the principle of estoppel by convention in Amalgamated [Investment $\&$ ] Property Co. v. Texas Bank [[1982] Q.B. 84, 122] so as to give rise to a cause of action, he was alone in stating the principle so broadly." [at p.31] Dillwyn v. Llewellyn (1862) $4 \mathrm{De}$ G. F. \& J. 517; 45 Eng. Rep. 1285 is older authority on which to base conversion of promissory estoppel from a shield to a sword.

30 John Swan, "Consideration and the Reasons for Enforcing Contracts" in Studies in Contract Law (eds. Barry J. Reiter \& John Swan) (Toronto, Butterworths, 1980) 23 states that if the subcontractor in a construction bidding case "has promised that the offer is to remain open for the time necessary to be incorporated into the bid of the general contractor, it might be possible to argue that the High Trees doctrine operates to restrict the subcontractor's power to revoke." [at p.51].

31 For example, see L.A. Sheridan, "Equity Estoppel Today" (1952) 15 M.L.R. 325 (the law should not be scarificed to the kind uncertainty of equity); D.M. Gordon, "Creditors' Promises to Forego Rights" (1963) 21 C.L.J. 222 (there is no theory of quasi-estoppel); Francis Bennion, "Want of Consideration" (1953) 16 M.L.R. 441 (common law judges should not usurp the function of the legislature). For particularly emotional rhetoric inspired by High Trees, see K.O. Shatwell, "The Doctrine of Consideration in the Modern Law" (1954)1 Sydney L.Rev. 289 at p. 307 who said that Denning J. made "a vigorous effort, if not to beget, 
dangerous novelty, ${ }^{, 32}$ Although there was a reaction against High Trees, it was not so violent as Rann v. Hughes was against Mansfield's emphasis on equity rather than consideration. Indeed, Lord Justice Denning, as he became soon after High Trees, probably had Rann in mind when he participated in reformulating promissory estoppel in Combe v. Combe, thereby hoping to blunt the backlash: it is clear he considered it a defeat. ${ }^{33}$

Two later extra-judicial comments explain why he took this position in Combe and indicate the care he took to protect the principle of promissory estoppel in High Trees. Lord Denning admitted that Combe "led to a fall" insofar as Lord Simonds in the House of Lords warned that Combe "may well be far too widely stated" and Lord Simonds therefore did "not wish to lend the authority of this House" to the principle that conduct or words intended to be acted on cannot later be ignored by the one who introduced the words or conduct into the relationship. ${ }^{34}$

at least to nurture a puny child of Equity's old age." The following studies provide different interpretations of High Trees: John F. Wilson, "A Reappraisal of Quasi-estoppel" (1965) 23 C.L.J. 93 (contract must respond to the needs of commercial constitutents); David Jackson, "Estoppel as a Sword" (parts 1 \& 2), (1965) 81 L.Q.R. 84 at p.223 (Denning L.J. himself undermined equitable estoppel in Combe v. Combe [see infra n. 33]); George Spencer-Bower \& Alexander K. Turner, The Law Relating to Estoppel by Representation (London, Boston, Butterworths, $3^{\text {rd }}$ ed., 1977) (the term equitable estoppel should be scorned).

32 John H. Baker, "From Contract to Reasonable Expectation" (1979) 32 Curr. Legal Probs. 17 at p. 25 .

33 The court in Combe v. Combe [1951] 2 K.B. 215 at 220; [1951] 1 All E.R. 767 at 770, with Denning L.J. reformulating promissory estoppel, retrenched. Cf. Southern California Acoustics Co. v. C.V. Holder Inc., 456 P. 2 d.975 (Cal. 1969) in which Chief Justice Traynor said there was no contract between Acoustics, the sub-contractor and Holder, the general contractor. Denning L.J. said in Combe: "Much as I am inclined to favour the principle stated in the High Trees case, it is important that it should not be stretched too far, lest it should be endangered." He also tried to reassure those who felt that consideration was threatened by High Trees: ". the doctrine is too firmly fixed to be overthrown by a side-wind. Its ill-effects have been largely mitigated of late, but it still remains a cardinal necessity of the formation of a contract, though not of its modification or discharge. I fear that it was my failure to make this clear which misled the Judge in the present case."

34 Alfred T. Denning, The Discipline of the Law (Butterworths, 1979) at p.209. (Lord Simonds set forth views in Tool Metal Manufacturing Co.Ltd. v. Tungsten Electric Co.Ltd. [1955] I W.L.R. 761 at 764; [1955] 2 All E.R. 657.) Atiyah, supra n. 14 at p. 233 concluded that once High Trees was "cut down" by the interpretation of Combe, High Trees was no longer a radical, forward-looking innovation but reactionary because it refused to recognize the old broader view of consideration.

Somewhat closer in time to High Trees and Combe, Lord Denning reflected on Rann v. Hughes that Lord Mansfield may well have been right but that he (Lord Denning of 


\section{THE DENNING LAW JOURNAL}

The widely divergent interpretations of High Trees are arrayed like a smorgasbord of choices at a buffet, and the answers to the questions about High Trees seem to change over time. ${ }^{35}$ Did High Trees abolish consideration $?^{36}$ Was a promise now binding without consideration? ${ }^{37}$ Was there a waiver in the sense of forebearance ${ }^{38}$ Was detriment necessary for High Trees to operate? ${ }^{39}$ Or was High Trees merely the reformulation of the classical doctrine of consideration $?^{40}$ At first, Denning thought he had suceeded in remedying some of the defects in the doctrine of consideration, especially with the Law Revision Committee's

Whitchurch) was too careful to abolish consideration ("The Way of the Iconoclast" (1960) 5 Journal of the Society of Public Teachers of Law (n.s.) 77 at pp.80-81. He further stated that "in law as in war, a frontal attack is not likely to succeed against a position that is strongly held. (Much better make an outflanking movement, as in the Hightrees case)." [at.p. 82] 35 "Opinion has subsequently divided over whether the doctrine is a dangerous novelty, a new application of the old equitable principle enunciated in Hughes an adaptation of the commonlaw doctrine of waiver, or merely the reformation of the classical doctrine of consideration." Baker, supra $\mathrm{n} .32$ at p. 25 .

${ }^{36}$ Tony Dugdale \& David Yates, "Variation Waiver and Estoppel ? A Reappraisal" (1976) 39 M.L.R. 680; John Adams, "Waiver Redistributed" (1972) 36 Conv. \& Prop.Law (n.s.) 245; Samuel J Stoljar, "The Modification of Contracts" (1957) 35 Canadian Bar Rev. 485. ${ }^{37}$ Soon after High Trees, Lord Justice Denning (as he had then become), stated in Combe v. Combe supra $\mathrm{n} .33$ at 770 , that promissory estoppel can never do away with consideration when that is an essential part of the cause of action.

${ }^{38}$ Geoffrey Marston \& Douglas W. Smith, "Consideration and the Discharge of Modification of Contracts" (parts 1 \& 2), (1970) I Australian Current Law Review 131-142, 163-170. See also Barry J. Reiter, "Courts, Consideration and Common Sense" (1977) 27 U. Toronto L.J. 439.

39 John F. Wilson, "Recent Developments in Estoppel" (1951) 67 L.Q.R. 330 at p.344 thought detriment was required. Denning, supra n.24 at p.68 thought not. Spencer-Bower and Turner, supra n.31 at pp.391-393, looking at the orthodox doctrine that detriment is required, formulated a broad test of detriment around the promisee's injury. Turner showed that the differences between these two views may not be so great. A broad test of detriment for promissory estoppel amounts to the same position Denning took by examining the justice or injustice of allowing the promisor to go back on a promise. Denning's formula is very close to the requirement of injury in the Restatement of Contracts $\S 90$ (1932), available for comparison when High Trees was decided in 1947

${ }^{40}$ Atiyah, supra n. 14 at pp. 181 \& 231 concludes that originally the dictum in High Trees (that the promise on which the promisee relied was a fully enforceable contractural promise) constituted a reformulation of consideration. Formerly lawyers could enquire "what are the considerations which lead a court to enforce a promise." After Combe, the promisee's action in reliance was no longer directly enforceable under the notion of consideration. 
1937 Report recommending changes in the doctrine of consideration. ${ }^{41}$

Nevertheless, the legislature did not act and changes in consideration appeared slow and minimal, so that Lord Denning's opinion evolved faster than the general trend in the law, at least until the discharge case of Williams v. Roffey in 1990.

The present English law of consideration, however, was largely developed since $1937 .^{42}$ In summary terms, the present law reflects a compromise between the views of Lord Mansfield, on the one hand, and Eastwood v. Kenyon, ${ }^{43}$ on the one hand: "that gratuitous promises on which the promisee has relied should either be fully binding or not be binding at all." Lord Denning's views, which had been remarkably stable from his law school days to the decision in High Trees, seemed to change after all the division of scholarly and judicial opinion over High Trees. Not long after High Trees, he said of consideration:
"It must be remembered that which amounts in legal theory to consideration is sometimes a real consideration and sometimes not. Consideration in law is sometimes a real consideration and sometimes it is a mere fiction devised to make a promise enforceable. ${ }^{345}$

The protective attitude toward consideration expressed in his 1952 article gave way to growing recognition of the role equitable considerations could play in the cases he decided. Many years after High Trees, Lord Denning reflected on a lifelong interest in the question of equity as it alleviated the "injustices" caused by strict, common law rules. ${ }^{46}$ He assessed the effect of High Trees as doing

\footnotetext{
41 The Statute of Frauds and the Doctrine of Consideration: Report of the English Law Revision Committee, Sixth Interim Report, Cmd. 5449, reprinted in (1937) 15 Canadian Bar Review 585.

42 Guenter H. Treitel, The Law of Contract (Sweet \& Maxwell, $9^{\text {th }}$ ed., 1995) at p. 149.

43 (1840) 11 Ad \& El. 438; 113 Eng. Rep. 482; [K.B.], which overruled past consideration, and symbolizes the rejection of moral obligation to enforce contracts. Lobban, supra n. 5 at pp.113-114.

${ }_{44}$ Treitel, The Law of Contract (Sweet \& Maxwell, $8^{\text {th }}$ ed., 1991) at p. 148 and similarly in the $9^{\text {th }}$ ed., at p. 148: the question remains "to what extent the law should protect a promisee who has reasonably acted in reliance on a promise which is not supported by consideration." Treitel characterises the present law as "a compromise solution, giving the promisee some remedy on the ground of such reliance." [at p. 149].

${ }^{45}$ Bob Guiness Ltd. v. Salomonsen [1948] 2 K.B. 42 at 45 (forebearance as consideration).

${ }^{46}$ Denning, supra n.34 at pp. 197-223. He told of being concerned about injustices he saw during his commercial practice in the 1920 s and of remembering a case citing Victorian precedents which he had read in law school and marked 'Suggest Estoppel' [at p.201]. He read the Victorian precedents themselves while editing a case book. Still later Dennning read
} 
"away with the doctrine of consideration in all but a handul of cases," and came to feel that consideration was replaced by a principle of justice and equity, "the better precept: 'My word is my bond,' irrespective of whether there is consideration to support it. ${ }^{\text {,47 }}$ Mansfield's "ties of natural justice and equity" might still bind. ${ }^{48}$

\section{III.ACADEMIC ADVOCACY OF CONSIDERATION IN PLACE OF ESTOPPEL AND MODIFICATION IN COURT ON REASONABLE CONSIDERATION: LORANGER REDUX}

Atiyah examined $C r a b b$ v. Arun D.C., a case that might have lent itself to being the English Loranger but in fact was not so treated by the court, in part because factually it was not the right case for consideration and in part because Lord Denning continued to use promissory estoppel, as he had done in High Trees. In Crabb, a land owner sold a part of his land to the District Council, a local authority, for housing, and part to $\mathrm{Crabb}^{49} \mathrm{The}$ Council planned to build a new road along the boundary between the two tracts of land. Crabb subdivided the land he bought, and needed a second point of access to the planned road for the southern part of the land. The owner and his architect met with the surveyor for the Council and came away with the impression that he would have additional access to the planned road. The surveyor soon after left a gap in the fence for Crabb's access. Crabb sold the northern tract of land, and then the Council fenced off the second point of access.

the recommendations in the Law Revision Committee Report of 1937, supra n.41, on the doctrine of consideration, and quoted the following recommendation as particularly meaningful for High Trees: "We therefore recommend that a promise which the promisor knows, or reasonably should know, will be relied upon by the promisee, shall be enforceable if the promisee has altered his position to his detriment in reliance on the promise." [at p.202]. Six months after he was appointed as a judge in the King's Bench, High Trees came before him.

47 Ibid at p.233. Cf. Denning, supra n. 28 at p. 5 .

48 In a waiver case, Panchaud Frere S.A. v. Et General Grain Co. [1970] 1 Lloyd's Rep. 53, Lord Denning said:"If the buyers choose not to read the documents, they must put up with the consequences. They must be treated as if they had read them. This was clearly the view of the Committee of Appeal of the London Corn Trade Association Ltd: and in a commercial matter like this, I like to hear the views of commercial men, just as Lord Mansfield did with his special jurymen."See supra n. 11 for Lord Mansfield's practice

${ }^{49}$ [1976] Ch. 179; [1975] 3 All E.R. 865. 


\title{
LORD MANSFIELD'S LEGACY
}

The landowner sued the Council for the access. The judge at first instance dismissed the action. The Court of Appeal held for the landowner on grounds of estoppel, saying that the owner had an enforceable equity. Lord Justice Lawton framed the following issue: "Did the parties agree that the plaintiff should have access on to the road at point B?" Lord Denning M.R. emphasized the basis of the estoppel in equity.

"Equity comes in, true to form, to mitigate the rigours of strict law. The early cases did not speak of it as 'estoppel.' They spoke of it as "raising an equity."

Lord Justice Scarman wrote to the same effect: "If the plaintiff has any right, it is an equity arising out of the conduct and relationship of the parties."

Lord Denning suggested in The Discipline of Law that the use of promissory estoppel has come to the fore:

\begin{abstract}
"Once a man gives a promise or assurance to his neighbour - on which the neighbour relies - he should not be allowed to go back on it. In stating the principle, and its extensions, the lawyers use the archaic word 'estoppel.' I would prefer to put it in language which the ordinary man understands: It is a principle of justice and equity...." 50
\end{abstract}

Lord Denning turned to the equity language of estoppel in order to do justice when it appeared that a straight contract analysis could not accomplish a just result. While Atiyah tried to use Crabb as an example of the invocation of promissory estoppel when it would have been possible to show that a contract had been made, ${ }^{51}$ other commentators could not find consideration in Crabb. ${ }^{52}$ Furthermore, $C r a b b$ is too vague to satisfy the requirement of certainty since the parties reached only an agreement in principle, although the District Council firmly encouraged Crabb. ${ }^{53}$

Corbin wrote:

\footnotetext{
${ }^{50}$ Denning, supra n.34 at p.223.

51 Patrick S. Atiyah, "When is an Enforceable Agreement Not a Contract? Answer: When It is an Equity" (1978) 95 L.Q.R. 174 at pp.174-78.

${ }^{52}$ P.J. Millet, "Crabb v. Arun D C - A Riposte" (1976) 92 L.Q.R. 342.

s3 Ibid at p.343.
} 


\title{
THE DENNING LAW JOURNAL
}

\begin{abstract}
"that the doctrine of consideration is many doctrines, that no definition can rightly be set up as the one and only correct definition, and that the law of contract is an evolutionary product that has changed with time and circumstance and that must ever continue so to change." 54
\end{abstract}

Atiyah felt that consideration was dead, but if consideration is defined in Corbin's terms as "the factors that make promises enforceable," then it cannot be abolished functionally. In this particular case, Professor Atiyah suggested what can only be described as an approach similar to Justice Braucher's analysis in Loranger. Indeed, both felt the power of Corbin's analysis. Atiyah concluded that English contract law had fallen into an "extraordinary conceptual morass," due to "outmoded ideas about the purpose and nature of the doctrine of consideration." 56

Concerning Crabb, Atiyah asked, "is there any reason why the plaintiff should not have been able to set up his action in reliance on the undertaking or agreement as a valid consideration?" ${ }^{57}$ Atiyah thought that the equity analysis suggested a judicial preference for the doctrine of promissory estoppel over the "old" law of contract even when both would give the same result. Atiyah suggests that the use of promissory estoppel involves "mere lip service to classical principles." the doctrine of consideration, and therefore of the role of contract law. One factor in the confusion is that the lines between the two theories are not clearly drawn because detrimental reliance is both central to promissory estoppel and constitutes one of the twin pillars of consideration. ${ }^{59}$ Atiyah gives these functional and policy justifications for the doctrine of consideration: contract has always been in need of an enforcement mechanism and although the limitation is paternalistic by safeguarding a person from making rash promises, underlying fairness tracks the concerns of benefit and detriment. ${ }^{60}$

54 Arthur L. Corbin, Corbin on Contracts (West Publishing Co., rev.ed., 1963) $\$ 109$ at p.489. For the approach of the authors of the 1995 edition, see Joseph M. Perillo \& Helen H. Bender, 2 Corbin on Contracts (West Publishing Co.) §5.1 at pp.3-8

55 Ibid at p.495.

56 Atiyah, supra n.51 at pp.174-78

57 Ibid at p. 177.

58 Atiyah, supra n.29 at pp. 147-148

${ }^{59}$ Ibid at pp.153-154.

${ }^{60}$ Atiyah, supra n.29 at pp. 147 \& 159-160. 
In trying to define consideration or the scope of contracts, we naturally concentrate more heavily on "infirm agreements owing to deficiencies of form" at the offer and acceptance stage of the proceedings. ${ }^{61}$ Contract modification during the operation of the contract itself also gives rise to difficulties from the need for fresh consideration to establish a valid concession, as the facts of High Trees show. In the context of this doctrine, commonly called the doctrine of sufficient consideration, John Wilson, as long ago as 1958, summarised the difficulties the doctrine of consideration presented as a result of the sometimes erroneous assumption that "no person who makes an informal gratuitous promise intends to be legally bound by it. ${ }^{362}$

Along with gratuitous modifications of agreements, Wilson referred to the following types of commercial promise which fall outside the scope of consideration: a "promise to perform an existing contractural duty owed to the promise;",63 and a "promise to accept a smaller sum in discharge of a debt of a larger amount. ${ }^{, 64}$ Wilson explained that the requirement of fresh consideration was designed to protect one party from being pressured by the other party, and that application of the doctrine of economic duress would allow some of these promises to be enforceable. Mr. Justice Denning reconciled High Trees with

${ }^{61}$ Stoljar, supra n.9 at p.5. Press, 1974) remarked: "Classical theory used consideration as the touchstone for such curious deductions as that offers expressed to be irrevocable were nevertheless revocable until accepted, that certain modifications of ongoing contracts are ineffective and that discharges of debtors on payment of less than the full amount of the debt are not binding on creditors."[p.76].

${ }^{63}$ Stilk v. Myrick (1809) 2 Camp. 317; 170 Eng. Rep. 1168 (the sailors failed to receive a bonus when two of their mates deserted). The lack of consideration is interpreted as a reason for promising at the time Stilk was decided. A.W. Brian Simpson, "Innovation in Nineteenth Century Contract Law" (1975) 91 L.Q.R. 247 at p.262.

Foakes v. Beer (1884) 9 App. Cas. 605 [H.L.]; [1881-85] All Eng. Rep. 106 (no consideration for discharge of contractural duties to pay a debt). Simpson, ibid at p.263 suggests that when offer and acceptance was used instead of moral obligation after Eastwood v. Kenyon (1840) 11 Ad.\& El. 438; 113 Eng. Rep., [K.B.], equitable estoppel (the old detriment consideration with a new name) was invoked to deal with Foakes v. Beer. John P. Dawson, "Economic Duress - An Essay in Perspective" 45 Mich. L. Rev. 253 (1947). ${ }^{64}$ Foakes v. Beer (1884) 9 App. Cas. 605, [H.L.]; [1881-85] All Eng. Rep. 106 (no consideration for discharge of contractural duties to pay a debt). Simpson, ibid at p.263 suggests that when offer and acceptance was used instead of moral obligation after Eastwood v. Kenyon (1840) 11 Ad.\& El. 438; 113 Eng. Rep., [K.B.], equitable estoppel (the old detriment consideration with a new name) was invoked to deal with Foakes v. Beer. John P. Dawson, ibid. 


\section{THE DENNING LAW JOURNAL}

Foakes v. Beer by saying that Foakes was decided on purely common law principles, without reference to equity. ${ }^{65}$ Equitable estoppel has been used to protect the debtor when modification was in order. ${ }^{66}$ Many years later in Williams v. Roffey, the Court of Appeal thought that promissory estoppel might apply to modify a construction contract. ${ }^{67}$ To express the concept of duress in other terms, Grant Gilmore suggested that "[m]odifications may be agreed to or discharges granted honestly, fairly, voluntarily on both sides and in good faith; or they may be the result of coercion, economic duress, bad faith and fraud." Gilmore therefore concluded that the courts should concentrate not on consideration as an imprecise protection against economic duress but on whether the agreements were made in good faith or bad faith.

Wilson and many other commentators before and since, including the English Law Revision Committee's report, prepared the way for the result in the recent modification case which took a flexible approach to consideration. ${ }^{69}$ In Williams

${ }^{65}$ [1947] 1 K.B. 130 at 133. Combining Ward v. Byham [1956] l W.L.R. 496 at 498; [1956] 2 All E.R. 318 at 319; and Williams v. Williams [1957] 1 W.L.R. 148; [1957] 1 All E.R. 305, Denning said that a promise to perform an existing duty is good consideration, provided the transaction does not violate public interest. For comment on duress and these cases see K.C.T. Sutton, "Promises and Consideration" in Essays on Contract ed. Paul D. Finn, (Law Book Co., Sydney, 1987) at pp. $35 \&$ 50-52 and Hooley, supra n.29 at pp.22-23 \& 34-35.

${ }^{66}$ See, for example, Lord Denning's opinion in D\& C Builders Ltd. v. Rees [1966] 2 Q.B.617 at 625 ; [1965] 3 All E.R. 837. Debtor offered a cheque for $£ 300$ in payment of a bill for over $\mathfrak{f 7 0 0}$. The debtor pressured the creditor to accept the cheque in full satisfaction for the debt by making it clear that creditor would otherwise get nothing. The Court of Appeal did not accept the debtor's argument that payment by cheque is a variation sufficient to support the partial discharge of a debt. "Normally payment by cheque, even of the full sum, affects only a conditional discharge of the debt so that the debt is extinguished only when the cheque is honoured and it would be inconsistent with normal business practice to have different rules for payment by cheque and by cash." Cheshire, Fifoot \& Furmston's Law of Contract (Butterworths, $13^{\text {th }}$ ed., 1996) at p.99.

${ }^{67}$ [1990] 1 All E.R. 512 at 513. Ian Brown \& Adrian Chandler, "Consideration and Contract Modification" [1990] Conv. \& Prop. Law 209 at p. 211 suggest that the implications of Williams for promissory estoppel itself is rendered redundant by the decision. However, if consideration is freed by Williams to operate logically, promissory estoppel could be resurrected to contend with the problems of reliance in relation to truly gratuitous promises. ${ }^{68}$ Gilmore, supra n.62 at p.76. Fredrich Kessler and Edith Fine, "Culpa in Contrahendo, Business in Good Faith and Freedom of Contract" (1964) 77 Harv. L. Rev 401 a generation ago showed the existence of a formidable number of cases dealing with the pre-contractural duty to bargain in good faith.

${ }^{69}$ Law Revision Committee, Cmd. 5449, supra n. 41: the abolition of the rule in Foakes, [at para.35]; the recognition of a promise to perform an existing contract duty as being supported by sufficient consideration [at para 36]. 
v. Roffey, the general contractor, Roffey, had a contract for the refurbishment of a block of twenty-seven flats, and subcontracted the carpentry work to Williams for $£ 20,000$. Without any provision for payment, the general contractor paid money on account ${ }^{70}$ After finishing the carpentry in nine flats, doing some preliminary work in all the rest, and getting $£ 16,200$ on account, the subcontractor was in financial difficulty from underestimating the cost of doing the work by $£ 3,783$ and from faulty supervision of the workers. The general contractor had penalties for lateness under the contract with owners of the apartment complex. At a meeting with the carpenter, the general contractor agreed to pay $£ 575$ more per flat as each flat was completed for an additional total of $£ 10,300$. Williams finished eight more flats but only got one further

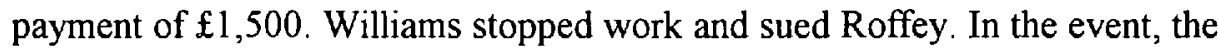
general contractor hired other carpenters but still incurred a one-week penalty under the general contract. The case turned on whether the carpenter gave consideration for the general contractor's promise to pay the additional money.

Although Hooley welcomes the Court of Appeal's desire "to see fair dealing during contract renegotiation," he is concerned not simply because the court departed from Stilk and its "rigid approach" to consideration, as Lord Justice Russell described Stilk, but also because Hooley wants other safeguards to carry out the functions of consideration.

On the other hand, Adams and Brownsword focus on the reasonabless and commercial usefulness of Russell's approach, thereby placing Russell in an older tradition than the classical, formalist position. ${ }^{71}$ The Court of Appeal concurred in the leading judgment of Lord Justice Glidewell, who said that the general contractor had to pay because the benefit to the general contractor is capable of being consideration for the general's promise, so that the promise will be legally binding. There is no detriment to the promisee, but a factual benefit to the promisor because the subcontractor's failure to complete on time would subject the general contractor to penalties for delay under his contract with the owner of the flats. Therefore, 'practical benefits' accrued to the general contractor from the modification. Lord Justice Glidewell confronted the precedent in Stilk and stated that the court was not "contravening" the principle of fresh consideration but only "refin[ing] and limit[ing] the application of that principle," thus leaving "the principle unscathed" when the promisor receives no benefit from promising. $^{72}$

${ }^{70}$ [1991] 1 Q.B. 1; [1990] 1 All E.R. 512.

71 Hooley, supra n.29 at p. 19. Russell L.J. in Williams v. Roffey [1990] 1 All E.R. 512 at 524.

72 John N. Adams \& Roger Brownsword, "Contract, Consideration and the Critical Path" (1990) 53 M.L.R. 536 at p. 541 


\section{THE DENNING LAW JOURNAL}

Commentators are still concerned about what Grant Gilmore called the good faith agreement and the balance of efficient breach versus moral hazard. ${ }^{73}$ Our use of exceptions from the general rule of consideration to accomplish the goal of good faith enforcement:
"makes the resulting pattern look a good deal more complicated than it really is, with the result that people - including lawyers and judges - are sometimes led astray. These extensions of consideration theory have also, since the 1930s, suffered considerable statutory erosion... The effect of such statutory abolition of a consideration requirement will be, I suggest, to drive out into the open what has always been the underlying principle of decision - the distinction between good faith and bad faith agreements." 74

Despite ending on a postive note, one assessment of Williams betrays worry that the courts may not be able to deal with the more complicated assessments required to determine duress and may therefore give rise to lack of certainty:
"Without ceremony, Williams strikes at the heart of consideration in substituting inetention and economic duress as the criteria for contractural validity... The reasoning in Williams is obscure, cautioning against any weakening of consideration without clearer safeguards." 75

But, as if in answer, Adams and Brownsword dismissed the temptation to stay 'with the old law." "The old law bought calculability only at the price of ignoring commercial reality"

\footnotetext{
73 [1990] 1 All E.R. 512 per Glidewell L.J. at 521-522.

${ }^{74}$ For the moral hazard problem, made familiar from experience in insurance law, see Louis Kaplow, "An Economic Analysis of Legal Transitions" (1986) 99 Harv. L. Rev. 509 at pp.536-542 (the provision of insurance may increase the probability of a loss or the size of a loss because the injured party has less incentive to take precautions).

${ }^{75}$ Gilmore, supra n.62 at pp.76-77; cf. Kessler \& Fine, supra n.68. Compare John P. Dawson, Gifts and Promises (Yale University Press, 1980) at p.211 on the inclusion of revocation of offers within offer and acceptance and consideration. Good faith has been related to the reasonable expectation that a contract would operate fairly.

${ }^{76}$ Brown \& Chandler, supra n.67 at pp.211-12.
} 
Adams and Brownsword find Williams a significant confirmation of "one of the leading themes of the death-of-contract school of thinking: namely, that so long as the promisee confers some reciprocal requested benefit on the promisor, it is not essential that detriment is incurred by the promisee." Treitel's tentative conclusion from the statements of Lord Justices Purchas, Glidewell and Russell:
"is that the factual benefit to [the general contractor] in securing [the subcontractor's] performance of the earlier contract will normally suffice to constitute consideration. The insistence in the earlier cases on the stricter requirement of legal benefit or detriment is no longer justified by the need to guard against extortion, now that this risk is more satisfactorily dealt with by the expanding concept of duress." 78

Like Loranger, Williams is couched in the traditional terms of consideration with a much broader scope, promissory estoppel having been foreclosed by the case itself. The author of Loranger would have welcomed the opportunity Williams presents for the reshaping of the definition and function of consideration in commercial cases. ${ }^{79}$

Compared with the British fact patterns for reliance, like High Trees, the bid situation in Loranger, Drennan and Gimbel has traditionally not been an immediately sympathetic or compelling choice on the equities, which seem to go the other way. The bargaining advantages do rest with the general contractors who would not usually be the object of equitable solicitude. General contractors' notorious use of "bid chiseling" by reopening bargaining with the subcontractor while claiming a continuing right to accept the original offer and "bid shopping" by delaying acceptance after the award of the general contract in an effort to find a lower price. Listing the subcontractors' names in the general contractor's bid for the general contract would prevent pressuring of the subcontractors after the general contract is awarded. On the one hand, general contractors do not list the names of the subcontractors on their bids no matter what laws a state makes, thus

77 Adams \& Brownsword, supra n. 72 at p.541.

78 Ibid at pp.536-537.

79 Treitel, supra n. 42 at p.91 of the $9^{\text {th }}$ edition. Brian Coote, "Consideration and Benefit in Fact and in Law" (1990) 3 Journal of Contract Law 23 at pp. $24 \& 28$ criticises this decision as "remote from received learning" because the court said performance constitutes fresh consideration when he thinks the better analysis is that consideration is unnecessary. On the other hand, Roger Halson, "Sailors, Subcontractors and Consideration" (1990) 106 L.Q.R. 183 welcomes Williams as a remedy to a defect in the law. 


\section{THE DENNING LAW JOURNAL}

foreclosing the issue of the subcontractor's reliance on the general contractor's use of its bid.

On the other hand, subcontractors may use mistake either to cover their unsuccessful attempts to negotiate their price upward or because of catastrophic rises in the price of their materials, thereby taking advantage of the general contractor. When the subcontractor in Baird v. Gimbel pleaded mistake in arriving at its linoleum bid by severely underestimating the square footage, Judge Learned Hand of the Second Circuit Court of Appeals found that the general contractor had not accepted the subcontractor's bid. The subcontractor's offer was a revocable offer since the general and subcontractors had not examined promises before the general contractor entered its own bid for the prime construction contract. Although the general and subcontractors may be adverse to each other's interest, neither may be said to represent the public interest. ${ }^{80}$

On closer examination, the fact pattern recommends itself for treatment as a contract, especially if one concludes that the most striking feature of these bidding agreements is the long-term nature of the relationships within the industry and often in individual building projects. ${ }^{81}$ The public interest may arise from this relationship rather than in here in either party. In Drennan, Justice Roger Traynor of the California Supreme Court saw that Star's offer to do the paving was not a promise but suggested that a promise was implied with the offer to keep the offer open because it wanted to induce Drennan to rely on its offer and thus obtain the subcontractor's work. According to Traynor, keeping the subcontractor's offer open in effect gave the general contractor an option. Justice Traynor used promissory estoppel to hold the option equivalent to consideration but this theory works only for the general contractor. It does nothing to let a subcontractor sue when the general contractor wrongfully dumps the subcontractor after the award of the general contract.

The unsympathetic facts which may surround either party do not conjure up equity but are central to what contract is about and throw the principles Justice Braucher was trying to clarify into relief. Justice Braucher held that the jury in

${ }^{80}$ Adams \& Brownsword, supra n. 72 at p.542 suggest that Williams may have released consideration "from shackles of the nineteenth century."

Michael L. Closen \& David G. Weiland, "The Construction Industry at Bidding Cases: Application of Traditional Contract, Promissory Estoppel and Other Theories to the Relationship between General Contractors and Subcontractors" $13 \mathrm{~J}$. Marshall L.Rev. 565 (1980) at p. 580 .

${ }^{81}$ Michael L. Closen \& David G. Weiland, "The Construction Industry at Bidding Cases: Application of Traditional Contract, Promissory Estoppel and Other Theories to the Relations between General Contractors and Subcontractors" (1980) 13 J. Marshall L.Rev. 565 at p.605. 


\section{LORD MANSFIELD'S LEGACY}

Loranger could reasonably have been the subcontractor's bid as an offer for a typical bargained exchange.He declined to use the term promissory estoppel in holding that Loranger's reliance on the offer of subcontractor, Hauserman, should render the offer irrevocable. Agreeing with Fuller on the ancient heritage of reliance, Braucher noted that the original enforcement of informal promises was based on the reasonable reliance of the promisee, long before any notion of consideration was conceived. ${ }^{82}$

In light of Justice Braucher's criticism of the term 'promissory estoppel' it would be expected of the Restatement (Second) of Contracts not to use it. Indeed there is mention in a comment to $\$ 90$ only to emphasise its historical roots in the action of assumpsit which measured damages by the extent of the reliance injury, and not the value of the promised performance. Since Braucher was the Reporter in 1965 for the Restatement, Loranger can be set in the context of the Restatement comments which now accompany $\S 90$ to indicate that $\S 90$ provides a most important working definition of contract. In the second Restatement, the ancient, more inclusive notion of consideration, which had been dispossessed during the $19^{\text {th }}$ century, was restored. Justice Braucher carefully refrained from using the term promissory estoppel, which had been the name for reliance duirng its exile under the dominance of classical $19^{\text {th }}$ century theory. $\mathrm{He}$ ruled that in order to protect the reliance interests of the promisee, the definition of consideration could be expanded to include an inference of a bargained exchange.

Thus the general contractor's reliance on the subcontractor's bid constituted bargained consideration sufficient to enforce a contract because of the reciprocal relation between the promise and the consideration in a typical bargain.

Consideration is expanded to include an implied-in-fact inference unlike Judge Hand's theory of consideration in Baird which did not encompass this firm offer situation. While only the subcontractor becomes bound in Drennan, Justice Braucher wanted to unite the two manifestations of consideration, bargain and reliance, and ensure that the same result is reached under both theories. If Justice Braucher's theory were followed, the subcontractor could sue the general in a bid shopping or bid chiseling situation. Braucher's efforts resonate with the changes in consideration elsewhere in the common law world, both in such academic writing as the work of Atiyah or the essays Paul Finn collected, and these

${ }^{82}$ John Bell, "The Effect of Changes in Circumstances" in Contract Law Today: AngloFrench Comparisons (eds. Donald Harris \& Denis Tallon) (Oxford, Clarendon Press, 1989) at pp.204-205 deals with rises in the cost of labour and material over the course of a building project. 


\section{THE DENNING LAW JOURNAL}

developments from classical contract law, are, in turn, the truly exciting illumination of Loranger. ${ }^{83}$ Nevertheless, Loranger is largely forgotten today.

\section{CONCLUSION: PROMISSORY ESTOPPEL'S PLACE IN TRADITIONAL CONTRACT IS ACKNOWLEDGED}

Lord Denning similarly felt that nineteenth century contract law unnecessarily and unfairly restricted recovery because consideration had been severely limited, and that an equity approach, which had originally arisen to mitigate the injustices of strict rules, was again needed to rescue the common law from inflicting injustices. His approach left behind the old terminology and started afresh with equity. Corbin, Atiyah, and Baucher wanted to retreat from some of the most severe pruning of $19^{\text {th }}$ century contract law andd set it back on its course from that point. For others less profoundly involved with history, perhaps the task of rehabilitating contract may not seem worth the effort. Or perhaps the result might not always have been the same, and the proponents of equity had enough opposition over the years from vocal $20^{\text {th }}$ century contract law. Indeed, Professor John Baker has pointed out the difference between exchange and estoppel for the implications of High Trees and Crabb. ${ }^{84}$

This uncertainty in the law today about whether a particular issue or analysis is or is not part of contract law impels several commentators, including Atiyah, to urge a clear analysis of the application of contractural detriment in the doctrine of consideration and detriment in estoppel. Their solution is to use conventional consideration doctrine to reach the same result as many of the cases invoking estoppel.
"Many decisions have been grounded on estoppel when their true basis should have been contractural... If these decisions had been made on the ground of contract, we should perhaps have been spared the difficulty of separating the requirement of detriment in estoppel from the contractural idea of consideration. ${ }^{~} 85$

\footnotetext{
83 Supra $\mathrm{n} .1$ at 179 , citing the draft of the Restatement (Second) of Contracts $\$ 90 \mathrm{cmt} \mathrm{a}$ (American Law Institute, 1981). Lon L. Fuller \& William R. Perdue, "The Reliance Interest in Contract Damages" (part 1) (1936) 46 Yale L.J. 52 at p.68 n.61 (although $\S 90$ applies especially to non-commercial situations, the reliance interested was protected at common law).

${ }^{84}$ See, in addition to the articles already cited, H.K. Lucke, "Good Faith and Contractural Performance" and Robin Cooke, "Tort and Contract" in Essays on Contract (ed. Paul Finn) (N.S.W. Law Book Co., 1987)

${ }^{85}$ Baker, supra n.32 at p.29.
} 
If, on the one hand, adherents of classical contract law might like to castigate a court for reaching a result they would not, adherents of promissory estoppel, on the other hand, would disagree with Atiyah's attempt because promissory estoppel had its own separate history after Eastwood v. Kenyon, and, as an eminent legal historian put it, enjoyed its finest hours in the Victorian House of Lords in such cases as Hughes v. Metropolitan Railway. ${ }^{86}$ After Loranger, which bids us to examine the history of the terminology closely, it is clearer than it had been for many years that "promissory estoppel" is a version of the broad concept of consideration, or in Simpson's terminology, is one of many considerations. Only its new, equitable name conceals its origins in consideration, perhaps to protect it from those in the ascendancy who denied its role in contract. When the common law grew too stiff or narrow, equity often came to the rescue, allowing old doctrines to survive with changed names. Braucher in effect expands the application of the bargained-for-exchange to encompass reliance, as earlier periods in history had done. This earlier, broader umbrella was also simpler to apply. Loranger, however, has not spawned a movement toward simplification but stands virtually alone outside of Massachusetts.

${ }^{86}$ Wilson, supra $\mathrm{n} .39$ at p. 330 .

According to Professor Baker at common law, "relationships are governed by rules rather than by uncertain notions of fairness" supra n. 32 at p. 35 . Therefore we are back to the choice of imperfect laws or broad standards exercised under the discretion of just judges. 